\title{
Sexual and Reproductive Health of Adolescent in Nepal
}

\author{
Shrestha $\mathbf{S}^{1}$ \\ ${ }^{1}$ School of Nursing and Midwifery, Karnali Academy of Health Science, Jumla, Nepal.
}

\section{Corresponding Author:}

\section{Sharmila Shrestha}

Karnali Academy of Health Science, Jumla, Nepal Email: sharmila_shr@hotmail.com

Every fifth person in the world i.e. around $20 \%$ of global population is adolescents and slightly more than this, in Nepal, adolescents comprise of 24 percentage. Adolescents in Nepal often face limited access to health information and services. Different factors like poverty, gender inequality, socio-economic status, social norms and tradition play crucial role in determining adolescent's access to sexual and reproductive health knowledge and available sexual and reproductive health services. Especially women in this context are more disadvantaged with regards to literacy, health and overall wellbeing. In Nepal adolescents comprise of 24 percentage and young people comprise of 33 percentage, which is a larger proportion to the global comparison. ${ }^{1}$ Though the government of Nepal has recognized adolescents and youth as under-served and vulnerable population with specific sexual and reproductive health needs, however only limited number for program has been implemented targeting these age groups. ${ }^{2}$

Various multilateral and bilateral organizations along with ministries, NGOs and CBOs have collaborated in identifying key strategies and approaches to reach adolescents with suitable sexual and reproductive health services. Though sexual activity starts fairly at early age, sex and sexuality is still not an openly discussed topic in Nepalese societies where there are strong traditional norms and beliefs. ${ }^{3}$ According to the Nepal Demographic Health Survey of 2011, 4.6\% of 15 to 19 years women were estimated having sexual intercourse by the age of 15 years and $40 \%$ of women aged between 20 and 24 had sexual intercourse by age 18 and $58 \%$ by age $20 .{ }^{4}$ The adolescents and young people have inadequate access to appropriate sexual and reproductive health information. ${ }^{5}$ This means the reproductive health (RH) situation of adolescents is not properly addressed with reference to Nepal. It is worse in rural area than in urban area due to lack of education, information and awareness programs. Adolescents' fertility is a major social and health concern. Teenage mothers are more likely to suffer from complication during pregnancy and child birth, which determine the health and survival of both mother and child.

In addition, the practice of early marriage or the child marriage is common in the most part of rural Nepal. Nepal had the third-highest teenage pregnancy rate in south Asia. According to World Bank, with 73 births per 1,000 women aged 15 to 19 years become mothers, when they not well prepared to become a mother either physically or mentally. ${ }^{6}$ of the 15 - to 19 -year-old girls who are already married (almost 30\%), an estimated $17 \%$ have at least one child and $86 \%$ are thought not to use any modern contraception. The contraceptive prevalence rate is very low accounting 29 percentages. The married teenagers are more at risk of maternal mortality due to pregnancy, childbirth complications and unsafe abortion.

Sexual and reproductive health status and behaviours of adolescents and youth in Nepal are drawing attention to academicians, policy makers, development partners and public health service providers. ${ }^{7}$ Two reasons largely appear for this. First, sexual and reproductive health behaviours of young people are significantly changing. Such changes have implications in socioeconomic and demographic outcomes. Second, adolescence and 
youth period is full of turmoil. Unless addressed and guided by young people friendly social systems, public policies and service delivery systems, the risk of health disadvantage multiplies because changing sexual and reproductive health behaviours have inherent risks. Young people's attempts to adjust with sexually maturing body, learning to deal with sexual desires, confronting with sexual attitudes, values, norms and practices, experimenting with sexual behaviours and developing an image of self-put them at a crossroad of risks where individual coping abilities and family supports are essential strategies to help them practice healthy behaviours.

The National Adolescent Health and Development Strategy of Nepal considers adolescents a key target group for information and services. ${ }^{4}$ Sex education has been made mandatory in schools and given more importance because it will inform the student's problems involved in sex and sexual health. Individuals that are well-informed about sex, sexual practices, child sexual abuse and sexually transmitted diseases are needed for the development of a society. Schools pave the path for students academically, socially and help them become a responsible citizen, and implementing sexual education for growing children and adolescents would create a generation of openminded and well-informed citizens. At higher secondary level, students are supposed to be taught basic sex education using a chapter in a textbook called Health, Population and Environment, however, has received little attention on it.

In Nepal, adolescents are highly vulnerable to poor sexual health outcomes such as sexually transmitted infections (STIs), Human Immunodeficiency Virus (HIV) infection and unplanned pregnancies, and this is all due to a limited general awareness, limited knowledge of comprehensive, and age-appropriate sexuality education. Even at a time of the internet and the immense spread of communication technology, the main sources of information available to many adolescents in Nepal about sex, HIV \& AIDS, abortion, menstrual hygiene, etc. are either their peers, magazines, or their course book which might not provide sufficient information to meet young adolescent curiosity. Limited sexuality education and understanding among adolescents come with widening circles of issues.

\section{Conflict of Interest: None}

\section{REFERENCES}

1. Ministry of Health and Population (MOHP), New ERA, and ICF International Inc. (2012)

2. Khatiwada N, Silwal PR, Bhadra R, Tamang TM. Sexual and reproductive health of adolescents and youth in Nepal: Trends and determinants. Further analysis of the 2011, Nepal Demographic and Health Survey

3. Mathur S, Malhotra A, Mehta M. Adolescent girls' life aspirations and reproductive health in Nepal. Reproductive Health Matters. 2001 Jan 1;9(17):91100

4. Ministry of Health and Population, New ERA, and ICF International, Calverton, Maryland. Nepal demographic and health survey 2011. Kathmandu

5. Acharya DR, Bhattarai R, Poobalan A, Teijlingen VE, Chapman G. Factors associated with teenage pregnancy in South Asia. 2014

6. The World Bank. (2014). Adolescent Health and Development. Washington DC: The World Bank. 2014

7. Pathak RS, Pokharel T. Sexual and Reproductive Health Status of Adolescents and Youth in Nepal. Nepal Population Journal. 2012; 17(16):131-3 